\title{
$\mathrm{PFC}$ 를 이용한 평면 파쇄가 전단 거동에 미치는 효과
}

김은경 ${ }^{1}$ 정다운 ${ }^{2}$, 이석원 ${ }^{3 *}$

\section{Surface roughness crushing effect on shear behavior using PFC}

\author{
Eun-Kyung Kim, Da-Woon Jeong, Seok-Won Lee
}

\begin{abstract}
The shear behavior at the particle/surface interface such as rock joint can determine the mechanical behavior of whole structure. Therefore, a fundamental understanding of the mechanisms governing its behavior and accurately estimation of the interface strength is essential. In this paper, PFC, a numerical analysis program of discrete element method was used to investigate the effects of the surface roughness crushing on interface strength. The surface roughness was characterized by smooth, intermediate, and rough surface, respectively. Particle shape was classified into one ball model of circular shape and 3 ball model of triangular shape. The surface shape was modelled by wall model of non-crushing surface and ball model of crushing surface. The results showed that as the bonding strength of ball model decreases, lower interface strength is induced. After the surface roughness crushing was occurred, the interface strength tended to converge and higher bonding strength induced lower surface roughness crushing. Higher friction angle was induced in wall model and higher surface roughness induced the higher friction angle. From these findings, it is verified that the surface roughness and surface roughness crushing effect on the particle/surface interface shear behavior.
\end{abstract}

Keywords: Discrete element method, particle flow code 2D, particle/surface interface, surface roughness, surface roughness crushing

요 약 암반 절리면과 같이 입자와 연속체 평면의 접촉면에서의 전단거동은 전체 구조물의 거동을 지배할 수 있다. 암반 설계의 효율을 높이기 위해서는 입자와 연속체 평면의 접촉면 전단거동 메커니즘에 대한 기초적인 이해와 접촉면 전단강도를 정확하게 산정하는 것이 필수적이다. 본 연구에서는 연속체 평면의 표면 파쇄가 미치는 영향을 알아보기 위하여 개별요소법 수치해석 프로그램인 $\mathrm{PFC}^{2 \mathrm{D}}$ 를 사용하였다. 표면 거칠기는 매끄러운 평면, 중간 거칠기 평면, 거친 평면의 세 가지로 구분하였다. 입자의 형상은 원형의 one ball 모델과 삼각형 형상의 3 ball 모델로 구성하였다. 평면은 파쇄가 불가능한 경계요소 연속체 모델과 파쇄가 가능한 입자요소 연속체 모델로 각각 구성하였다. 수치해석 결과, 입자요소 모델의 결합강도가 작을수록 파쇄가 빨리 발생하여 큰 결합강도를 가진 연속체 모델보다 작은 접촉면 전단강도를 보였다. 돌출부의 파쇄가 발생한 후, 접촉면 전단강도는 수렴하는 경향을 보이며, 결합강도가 클수록 돌출부의 파쇄가 적게 발생하였다. 또한 경계요소 연속체 모델이 입자요소 연속체 모델보다 큰 접촉면 마찰각을 나타냈고, 모든 입자 모델에서 연속체의 표면 거칠기가 거칠수록 큰 접촉면 마찰각이 나타났다. 이러한 결과로부터 연속체 평면의 거칠기 및 평면 파쇄가 입자와 평면의 접촉면 전단거동 특성에 미치는 영향을 확인하였다.

주요어: 개별요소법, $\mathrm{PFC}^{2 \mathrm{D}}$, 입자/평면 접촉면, 표면 거칠기, 평면 파쇄

접수일(2012.06.26), 수정일(2012.07.04), 게재확정일(2012.07.11)

${ }^{1}$ 건국대학교 사회환경시스템공학과 석사

${ }^{2}$ 건국대학교 사회환경시스템공학과 석사과정

${ }^{3}$ 건국대학교 사회환경시스템공학과 부교수

*교신저자: 이석원 (E-mail: swlee@konkuk.ac.kr) 


\section{1. 서 론}

흙 입자와 암반 절리면, 흙 입자와 콘크리트 표면, 흙 입자와 토목섬유 등과 같이 입자/평면 접촉면에서의 전단거동 특성은 지반 공학적 문제에 많은 영향을 미친다. 예를 들어, 암반 절리면, 터널 라이닝, 깊은 기초(말뚝 기초), 옹벽 구조물 등과 같은 많은 지반 구조물의 안정성을 결정하는 중요한 요소가 될 수 있다. 입자/평면 접촉면에서 전단 강도를 결정하는 데는 시험 조건뿐만 아니라 입자 및 평면의 물성이 크게 영향을 미치며, 따라서 이에 대한 연구가 활발하게 이루어져 왔다(이성원 등, 2009; 조인성 등, 2010; 김도훈 등, 2011; Potyondy, 1961; Brumund and Leonards, 1973; Uesugi et al., 1988; Paikowsky et al., 1995; Dove et al., 1997; Lee, 1998; Frost et al., 1999).

흙 입자와 절리면과 같은 연속체 평면과의 접촉면에서의 전단 거동은 입자의 형상, 입자의 파쇄 여부, 표면의 거칠기, 표면의 파쇄 유무 등에 밀접한 관계를 가지고 있다. 예를 들어, 입자 및 평면 파쇄 관점에서 보면 입자/평면 접촉면에서 외부로부터 작용되는 응력에 의하여 입자 및 평면 구조가 파쇄될 수 있으며, 이러한 입자 및 평면의 파쇄는 전체 지반의 특성을 변화시키고 구조물의 불안정성을 유발할 수 있다. 이러한 입자 및 평면 파쇄의 시각화를 위하여 Cundall and Strack(1979)에 의해 개발된 개별요소법(DEM, Distinct Element Method)이 널리 이용되고 있다(Lobo-Guerrero and Vallejo, 2005; Feda, 2002; Jensen, 1998).

본 연구에서는 개별요소법을 기반으로 하는 수치해석 프로그램인 $\mathrm{PFC}^{2 \mathrm{D}}$ (Particle Flow Code)를 이용하여 입자와 연속체 평면의 접촉면에서의 전단거동 특성을 연구하였다. 특히 본 연구에서는 기존의 연구와는 다르게, 전단이 진행됨에 따라 입자와 연속체 평면 모두 파쇄가 가능하도록 모델링하여 접촉면 전단거동에 입자 및 평면의 파쇄가 미치는 영향을 분석하였다. 이 때, 입자는 원형의 단일입자와 3 개의 작은 원형입자의 결합으로 이루어져 입자간 결합이 영구적인 clump 모델 및 입자간 접촉점에 결합력을 부여하여 주어진 결합강도(bond strength) 이상의 외력을 받으면 결합이 파괴되는 cluster 모델로 각각 구성하여 입자의 형상 및 파쇄에 따른 접촉면 전단거동 특성을 연구하였다. 또한 연속체를 파쇄가 불가능한 경계요소(wall) 연속체와 파쇄가 가능한 입자요소(ball) 연속체로 각각 모델링하여 연속체 평면의 표면 돌출부 파쇄로 인한 접촉면 전단거동 특성의 변화를 연구하였으며, 이 때 연속체 평면의 표면 돌출부의 각도에 변화를 주어 표면 거칠기 변화에 따른 영향 또한 비교·분석하였다. 본 연구에서는 입자와 연속체 평면의 파쇄 및 연속체 평면의 표면 거칠기에 따른 접촉면 전단거동 특성 변화를 상대적으로 비교하고자 하였다. 따라서 본 연구의 주된 목적은 실내실험으로부터 얻은 특정 결과 값을 비교하고자 함이 아니라, 수치해석을 통해 입자 및 평면의 파쇄로 인한 입자와 연속체 평면의 접촉면 전단거동 특성 변화에 대한 정량적인 분석이다. 


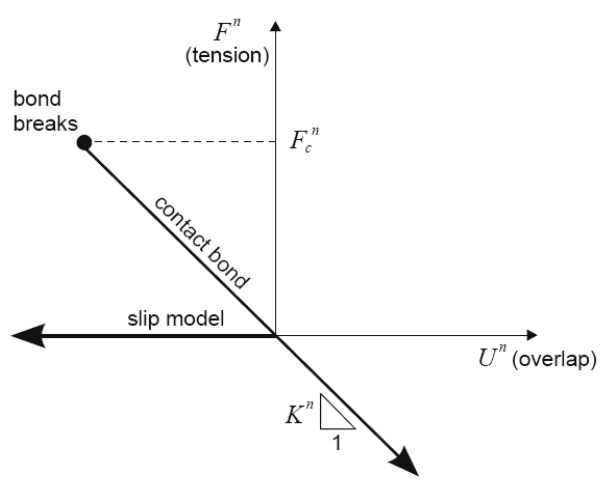

(a) 수직 접촉력과 파괴 조건

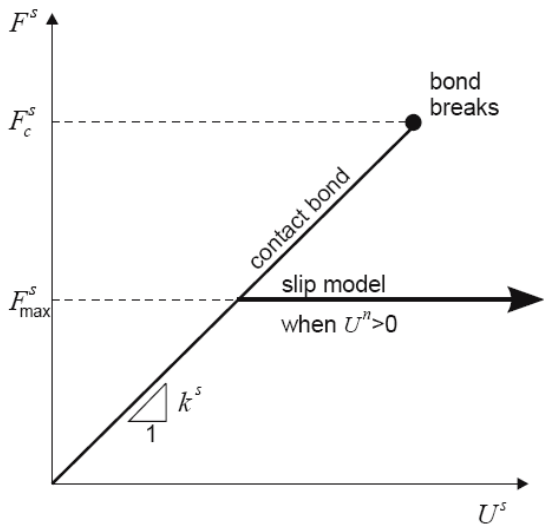

(b) 전단 접촉력과 파괴 조건

그림 1. 접촉점에서의 구조적 거동

\section{2. 해석 프로그램}

본 연구에서는 개별요소법(DEM)을 기본으로 하는 상용해석 프로그램인 $\mathrm{PFC}^{2 \mathrm{D}}$ 를 이용하여 입자평면 접촉면 전단 거동에 관한 연구를 수행하였다. 개별요소법은 해석 대상의 구조체를 개별적인 구형 입자의 집합체로 모델화 한다. 개개의 구형 입자는 운동방정식에 따라 독립적으로 운동하며, 이 때 발생하는 입자의 상호작용을 기본으로 해석이 이루어진다. 개별요소법을 이용하여 접촉면 전단영역에서 발생하는 입자의 맞물림(interlocking) 효과, 입도분포 및 간극률의 영향 등을 고려할 수 있고 입자의 파쇄를 정량적으로 관찰할 수 있다.

$\mathrm{PFC}^{2 \mathrm{D}}$ 에서 입자들은 상호간 접촉에서 전개되는 힘을 통하여 다른 입자 및 벽과 상호 작용하고, 접촉은 반드시 두 개의 요소들(ball-ball or ball-wall)과 관련되어 있으며, 하나의 점에서 발생한다. 입자의 기본 형상이 원형인 $\mathrm{PFC}^{2 \mathrm{D}}$ 내에서 입자간 접촉에서의 결합으로 불규칙 형상의 입자를 모델링할 수 있으며, 불규칙 형상이 가능하도록 하는 것은 clump와 cluster 개념이다. 여기서 clump 모델은 영구적인 결합력으로 인하여 파쇄 모사가 불가능한 반면, cluster 모델은 유한한 결합력을 부여하여 그 이상의 외력을 받으면 결합이 파괴되어 입자 파쇄 모사가 가능하다. 접촉 결합은 수직 성분(normal component)과 전단 성분(shear component)으로 나누어 계산된다. 그림 1(a)는 접촉점에서의 인장력이 수직방향의 결합강도 즉, 인장강도에 도달하면 결합이 깨지고 수직 및 전단 접촉력은 상실됨을 나타낸다. 그림 $1(\mathrm{~b})$ 의 전단성분도 마찬가지로 전단 접촉력이 전단방향의 결합강도 즉, 전단강도에 도달하면 결합은 깨지지만 접촉력은 그대로 존재함을 나타낸다. 


\section{3. 수치해석 모델}

\section{1 입자 모델링}

$\mathrm{PFC}^{2 \mathrm{D}}$ 내에서 지원하는 입자는 원기둥 또는 구형으로 2 차원일 경우 단위 폭을 갖는 원기둥으로 간주되며, 3 차원에서는 구로서 모델링 되며 각각의 입자들에 물성을 부여하게 된다. $\mathrm{PFC}^{2 \mathrm{D}}$ 의 입자에 관한 입력 변수로는 입자의 크기, 강성, 마찰계수, 입자간의 결합력 등이 있다. 본 수치해석에 사용된 입자 형상은 그림 2 와 같이 원형의 단일입자인 one ball 모델(그림 2(a))과 삼각형 형상인 $3 \mathrm{ball}$ 모델(그림 2(b))의 두 가지로 구성하였고, 세 개의 작은 입자의 결합으로 이루어진 삼각형 형상의 전체 입자 면적은 원형의 입자 면적과 같게 하였다. 볼 입자의 크기는 기존의 연구결과(Jo et al., 2011)를 토대로 국부적 간극비의 변화를 세밀하게 관찰할 수 있도록 반지름을 $0.36 \mathrm{~mm}$ 로 결정하였다.

삼각형 형상 입자는 입자 결합 상태에 따라 비파쇄 입자 모델(clump 모델)과 파쇄 입자 모델(cluster 모델)로 구분하여 모델링하였다. 여기서 clump는 2 개 이상의 원형 입자들을 서로 결합시켜 접촉점의 파괴가 영구적으로 발생하지 않도록 함으로써 형상을 갖는 입자가 전단거동 과정에서 자신의 모양을 그대로 유지하는 모델이며, cluster는 입자간 접촉점에 부여한 결합강도 이상의 외력을 받으면 결합이 파괴되는 모델이다. 이 때, cluster 모델의 결합강도는 Jo et al. (2011)의 연구 결과를 바탕으로 각각 $200 \mathrm{kPa}$ 과 $800 \mathrm{kPa}$ 을 부여하였다. 따라서 one ball 모델과 clump 모델의 결과 비교로부터 입자 형상의 영향을 연구하였고, clump 모델과 cluster 모델을 비교함으로써 입자 파쇄의 영향에 대해 연구하였다. 입자 생성은 전단박스 범위에서 무작위 생성 원리를 이용하고, Hainbuchner et al. (2002)의 연구결과를 바탕으로 간극률 (n)은 상대밀도 $80 \%$ 를 기준으로 하여 0.135 (간극비, $e=0.156$ )를 적용하였다. 그 밖에 입력 변수들은 수치해석 보정과정(calibration)을 통하여 적절한 값을 산정하였고, 최종적으로 얻은 입자의 물성은 표 1 과 같다. 여기에서 입자간의 수직 및 전단 강성은 기존의 연구결과(Jo et al., 2011)를 토대로 결정하였다.

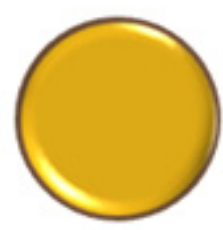

(a) one ball 모델

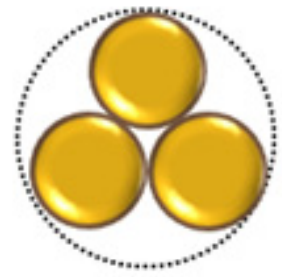

(b) 3 ball 모델

그림 2. 입자 모델링 
표 1. 입자와 연속체 평면 접촉면 모델의 입력 물성

\begin{tabular}{c|c}
\hline 입력 변수 & 값 \\
\hline 입자 밀도 $\left(\mathrm{kg} / \mathrm{m}^{3}\right)$ & 2,650 \\
\hline 입자의 수직/전단 강성 $(\mathrm{N} / \mathrm{m})$ & $1 \times 10^{8}$ \\
\hline 입자의 마찰계수 & 0.75 \\
\hline 파쇄 평면의 수직/전단 강성 $(\mathrm{N} / \mathrm{m}):$ ball 모델 & $1 \times 10^{8}$ \\
\hline 비 파쇄 평면의 수직/전단 강성 $(\mathrm{N} / \mathrm{m}):$ wall 모델 & $1 \times 10^{10}$ \\
\hline 평면의 마찰계수 & 0.364 \\
\hline 중력 $\left(\mathrm{m} / \mathrm{s}^{2}\right)$ & 9.81 \\
\hline 입자 반지름 $(\mathrm{mm})$ & 0.36 \\
\hline 입자 초기 간극률 & 0.135 \\
\hline 연속체 평면을 구성하는 볼의 반지름 $(\mathrm{mm})$ & 0.24 \\
\hline
\end{tabular}

\section{2 연속체 평면 모델링}

본 연구에서 연속체 평면의 모델링 방법은 입자와 연속체 평면의 접촉면 전단거동 특성 연구에 가장 중요한 요소로써 강성체인 경계요소(wall) 연속체와 표면 돌출부의 파쇄 모사가 가능한 입자요소(ball) 연속체를 각각 모델링하여 연속체 평면의 파쇄가 접촉면 전단거동 특성에 미치는 영향을 분석하였다.

\subsection{1 입자요소 연속체 모델(ball 모델)}

입자요소 연속체는 입자로 특정 각도를 갖는 돌출부를 연속체 평면에 형성시킴으로써 전단에 의해 돌출부의 파쇄가 가능하도록 한 것이다. 이 때 연속체 평면을 구성하는 입자들 전체에 결합력을 달리 부여하여 연속체 평면의 결합강도에 따른 접촉면 전단강도를 비교하였다. 여기에서 평면의 결합강도란 평면을 구성하는 입자들의 결합강도를 의미한다. 연속체 표면 거칠기는 돌출부의 각도를 $0^{\circ}, 15^{\circ}, 30^{\circ}$ 로 모델링하여, 정성적 표현으로 각각 매끄러운 평면, 중간 거칠기 평면, 거친 평면을 대표할 수 있도록 하였다. 그림 3은 입자요소 연속체 모델 중, 격자각도가 $30^{\circ}$ 일 때를 예로 접촉면 전단시험 모델링 과정을 나타낸 것이다. 먼저 그림 3(a)와 같이, 폭 $60 \mathrm{~mm}$, 높이 $20 \mathrm{~mm}$ 인 직사각형의 전단박스를 반으로 나누어 상·하부 경계면에 격자 간격이 $10 \mathrm{~mm}$ 이며, 각각의 거칠기를 갖는 임시의 벽(wall)을 만든다. 그 다음, 그림 3(b)에서 보는 바와 같이, 나누어진 하부박스에 연속체를 구성하는 입자들을 생성시켜 입자 전체에 결합력을 부여한 후, 그림 3(c)와 같이, 상부박스에 각각의 형상 및 결합 형태에 따른 입자 모델을 생성시켜 힘의 평형을 이루게 한다. 이 후 마지막 단계로 그림 3(d)와 같이, 경계면의 막음벽을 제거한 뒤 전단을 진행시키는 것이다.

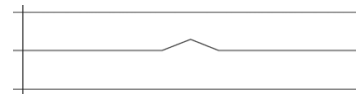

(a) 막음벽 생성

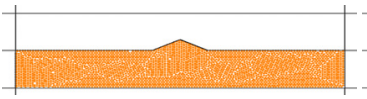

(b) 하부박스 입자 생성

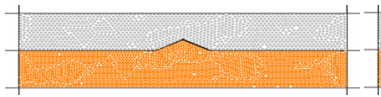

(c) 상부박스 입자 생성

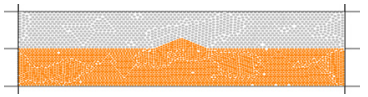

(d) 막음벽 제거

그림 3. 입자/평면 접촉면 모델 생성 과정 


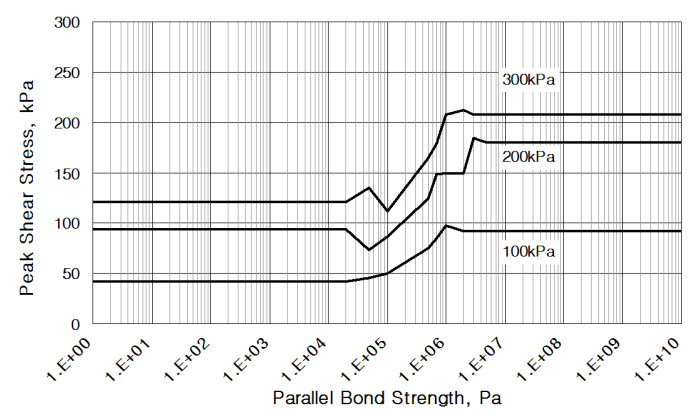

그림 4. 연속체 평면 결합강도와 최대 접촉면 전단강도와의 관계

전술한 바와 같이 입자요소 연속체는 일정 결합력으로 입자들을 묶어서 파쇄가 가능한 평면을 구성하였다. 이때 결합력은 다음과 같이 산정하였다. 그림 4는 대표적으로 거친 평면을 구성하는 입자들의 결합강도에 따른 one ball 모델의 최대 접촉면 전단강도를 보여주고 있다. 이 때 연속체 입자의 결합강도가 $3 \mathrm{MPa}$ 이상에서는 one ball 모델의 최대 접촉면 전단강도의 변화가 거의 나타나지 않는다는 것을 확인할 수 있다. 이는 주어진 결합강도가 한계값보다 큰 경우에는 전단으로 인한 돌출부의 파쇄가 발생하지 않아 접촉면 전단거동의 차이가 나타나지 않기 때문이다. 따라서 본 연구에서는 최대 접촉면 전단강도가 급격히 증가하기 시작하는 값인 $7 \times 10^{5} \mathrm{~Pa}$ 과 최대 접촉면 전단강도가 거의 일정하게 유지되기 시작하는 값인 $3 \times 10^{6} \mathrm{~Pa}$, 이 두 결합강도의 중간 값으로 $1 \times 10^{6} \mathrm{~Pa}$ 을 선택하여 수치해석에 적용하였다.

\subsection{2 경계요소 연속체 모델(wall 모델)}

경계요소 연속체는 그림 3(a)와 같이 임시 벽(wall)을 생성시키고 이것을 제거하지 않고 상부박스에 입자만 생성시켜 전단을 진행하였다. 그럼으로써 입자요소 연속체와 같은 돌출부 각도를 가지지만 파쇄가 불가능한 경계요소 평면 연속체가 만들어져 돌출부 파쇄가 발생하는 입자요소 평면 연속체와의 비교가 가능하도록 하였다. 그 밖에 입력 변수들은 수치해석 보정과정(calibration)을 통하여 적절한 값을 산정하였고, 최종적으로 얻은 평면의 물성은 표 1과 같다.

입자평면 접촉면 직접전단 모델은 그림 3과 같이 상부 박스와 하부 박스로 구분하여 모델링 하였다. 상부 박스는 4 개의 벽으로 구성되며 좌우 벽은 고정되어 있다. 윗벽은 상하로 이동이 자유로우며 servo-controlled system(Itasca Consulting Group, 2004)에 의하여 수직응력을 일정하게 유지시키는 역할을 한다. 전단 변위는 상부박스를 구성하는 벽들이 우측으로 이동하면서 이루어진다. 이 때 최대 전단변위는 돌출부 형상 시작 직전까지 거리인 $25 \mathrm{~mm}$ 로 하였고, 전단 속도는 $1 \mathrm{~mm} /$ 분으로 일정하게 유지하였다. 


\section{4. 입자/입자요소 연속체 평면 접촉면 전단거동 특성}

\section{1 입자요소 연속체 평면의 결합강도에 따른 전단거동}

$\mathrm{PFC}^{2 \mathrm{D}}$ 에서 지원하는 입자요소(ball)로 연속체 평면에 표면 돌출부를 모델링함으로써 입자뿐만 아니라, 연속체 평면의 돌출부 파쇄의 영향으로 인한 접촉면 전단거동 특성의 분석이 가능하다. 본 연구에서는 연속체 평면을 구성하는 입자 집합체의 결합강도에 변화를 주어 그에 따른 입자 및 연속체 표면 돌출부의 파쇄 유형을 분석하였다. 이 때 연속체 평면의 결합강도는 전술한 바와 같이 $700 \mathrm{kPa}, 1 \mathrm{MPa}, 3 \mathrm{MPa}$ 을 각각 적용하였다.

그림 5 는 연속체 평면을 구성하는 입자들의 결합강도에 따른 연속체 표면 거칠기별 응력-변위 곡선을 나타낸 것으로, 상부 입자가 one ball 모델인 경우이다. 이 때 수직하중은 $300 \mathrm{kPa}$ 이다. 그림 5(a)에서 보인 바와 같이 매끄러운 평면에서 one ball 모델의 접촉면 전단강도는 초기에 최대 접촉면 전단강도 값이 뚜렷하지 않다. 또한 결합강도가 작은 경우는 연속체를 구성하는 입자간 결합이 파괴되어 전단 후반부에 약간의 접촉면 전단강도의 감소를 보인다. 반면, 그림 $5(\mathrm{~b}),(\mathrm{c})$ 의 중간 거칠기 평면 및 거친 평면에서는 초기에 최대 접촉면 전단강도가 뚜렷이 나타났으며, 전단 초기에는 모든 결합강도에서의 곡선이 같은 그래프를 그리고 있으나, 결합강도가 상대적으로 작은 모델은 돌출부의 파괴가 발생하는 전단 변위에서 응력-변위 곡선이 달라지며, 큰 결합강도를 가진 모델보다 작은 최대 접촉면 전단강도를 보였다. 이 때 돌출부의 파쇄가 발생한 후, 접촉면 전단강도는 어느 정도 수렴하는 경향을 보이며, 가장 빨리 돌출부가 파괴되고 가장 큰 돌출부 파괴 영역을 보이는 결합강도 $700 \mathrm{kPa}$ 에서 잔류응력이 잘 나타난다. 또한 중간 거칠기 평면보다 거친 평면의 접촉면 전단강도가 크게 나타났으며, 거친 평면에서 최대 접촉면 전단강도를 더 뚜렷하게 발견할 수 있다.

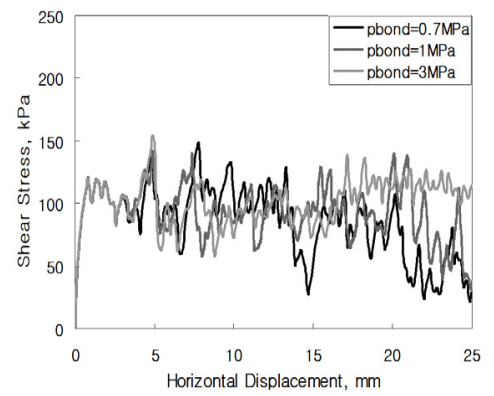

(a) 매끄러운 평면

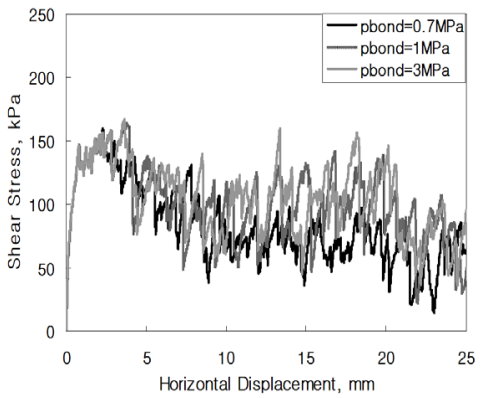

(b) 중간 거칠기 평면

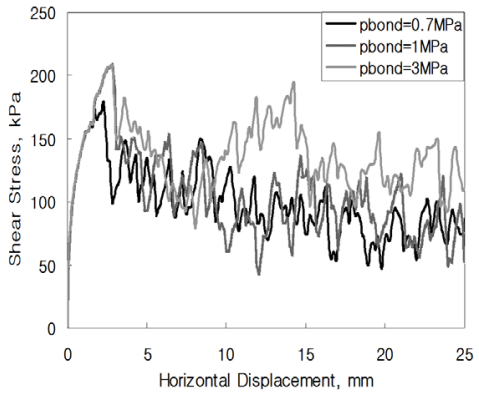

(c) 거친 평면

그림 5. 평면의 결합강도에 따른 one ball 모델의 응력-변위 곡선 


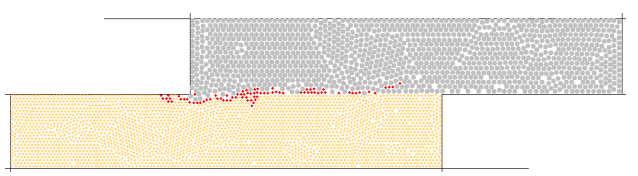

(i) 결합강도 $700 \mathrm{kPa}$

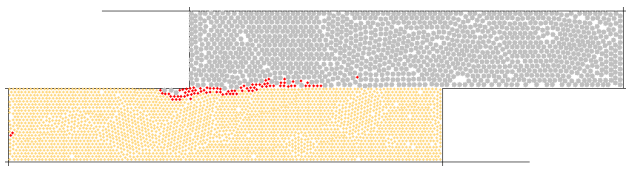

(ii) 결합강도 $1 \mathrm{MPa}$

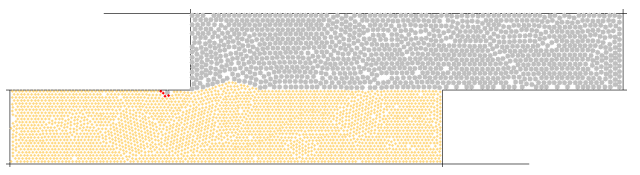

(iii) 결합강도 $3 \mathrm{MPa}$

(a) 중간 거칠기 평면

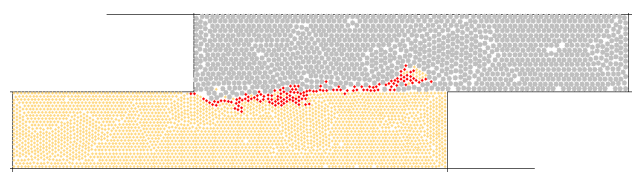

(i) 결합강도 $700 \mathrm{kPa}$

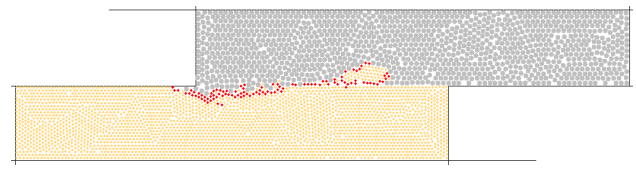

(ii) 결합강도 $1 \mathrm{MPa}$

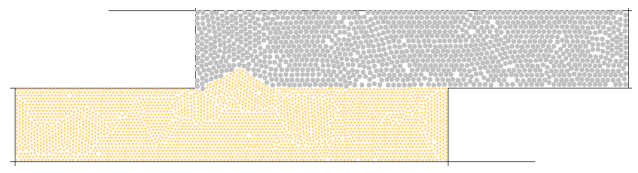

(iii) 결합강도 $3 \mathrm{MPa}$

(b) 거친 평면

그림 6. One ball 모델의 결합강도에 따른 표면 돌출부 파쇄 형태

한편 그림 6 은 그림 5 의 응력-변위 곡선을 나타내는 모델의 결합강도별 연속체 표면 돌출부의 파쇄 형태를 도시한 것이다. 중간 거칠기 평면과 거친 평면에서 모두 결합강도가 클수록 돌출부의 파쇄가 적게 발생하는 것을 확인할 수 있다. 또한 돌출부 영역이 똑같이 모두 파쇄되는 경우이더라도 파쇄 시점에 따라 파쇄된 입자의 분포가 달라진다. 즉, 결합강도 $700 \mathrm{kPa}$ 과 $1 \mathrm{MPa}$ 조건에서 모두 연속체 표면 돌출부의 전 영역이 파쇄되었지만 결합강도가 $700 \mathrm{kPa}$ 일 경우에 결합이 파괴된 입자가 더 멀리 이동하였다. 이는 결합강도에 따라 돌출부의 결합 파괴 발생 시점이 다르기 때문인 것으로, 빨리 돌출부의 파쇄가 발생하는 경우 파쇄된 입자의 이동거리가 멀어지는 것이다. 한편 거친 평면의 돌출부 파쇄 형태를 보면 중간 거칠기 평면과 달리, 돌출부가 덩어리째로 떨어져 나간 부분을 확인할 수 있는데, 이는 전단 시 돌출부 하단의 결합이 먼저 파괴되어 돌출부를 덩어리째로 이동시키기 때문이다. 이러한 접촉면 모델은 돌출부의 덩어리 파괴로 인해 전단거동 특성에 영향을 미치며, 전단강도의 수렴이 나타나지 않고, 응력-변위 곡선의 fluctuation을 증대시키는 원인이 될 수 있다고 판단된다.

\section{2 상부 입자의 형상 및 파쇄 유무에 따른 전단강도}

본 절에서는 입자 세 개의 결합으로 구성된 clump 및 cluster 모델과 입자요소 연속체 평면과의 접촉면 전단거동 특성을 one ball 모델과 비교함으로써 상부박스에 생성되는 입자의 형상 및 파쇄가 접촉면 전단거동 특성에 미치는 영향을 알아보고자 하였다. 
그림 7은 중간 거칠기 평면 및 거친 평면에서 one ball 모델과 clump 및 cluster 모델을 비교하여 응력-변위 곡선을 나타낸 것으로, 이 때 수직하중 조건은 $300 \mathrm{kPa}$ 이고 cluster 모델의 입자의 결합강도는 $800 \mathrm{kPa}$ 이다. 이로부터 전단초기에 각 입자 모델의 접촉면 전단강도는 결합강도에 관계없이 같은 곡선을 그리며, 같은 입자 형상으로 전단이 시작되는 clump 모델과 cluster 모델 중 cluster 모델은 입자 파쇄로 인해 접촉면 전단강도가 clump 모델보다 작게 나타났다. 또한 평면의 결합강도가 700 $\mathrm{kPa}$ 로 작은 경우에는 전단 초기에 입자에 따라 다른 접촉면 전단강도 값을 가지지만 이후 전단이 어느 정도 진행된 상황에서는 세 가지 입자 모델의 잔류 접촉면 전단강도가 유사한 값을 나타내고 있다. 이는 입자 모델에 따라 돌출부의 파쇄 시점이 다르기 때문인 것으로 판단되며, 돌출부 파쇄 후 접촉면 전단강도는 수렴하는 것으로 나타났다. 두 표면 거칠기 조건에서 모두 접촉면 전단강도는 입자 표면 형상이 굴곡지고 입자 파쇄가 발생하지 않는 clump 모델이 가장 컸고, 굴곡진 입자 표면을 가지지만 입자 파쇄가 발생하는 cluster 모델, 입자 표면이 둥근 단일입자인 one ball 모델 순으로 크게 나타났다.

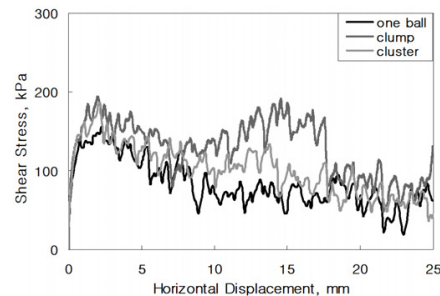

(i) 결합강도 $700 \mathrm{kPa}$

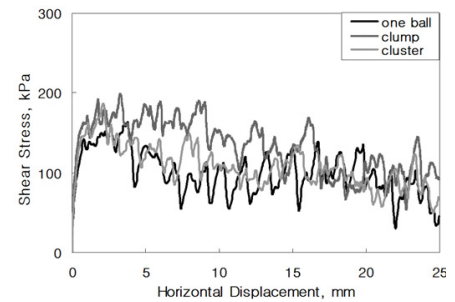

(ii) 결합강도 $1 \mathrm{MPa}$

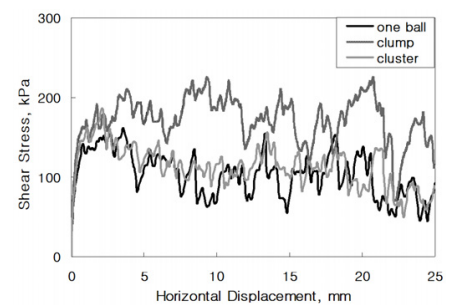

(iii) 결합강도 $3 \mathrm{MPa}$

(a) 중간 거칠기 평면

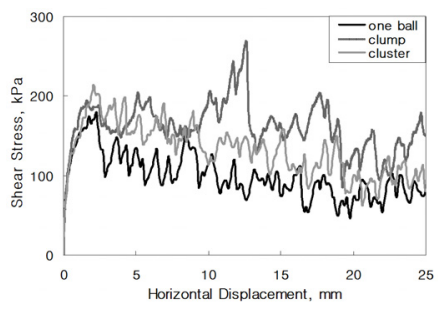

(i) 결합강도 $700 \mathrm{kPa}$

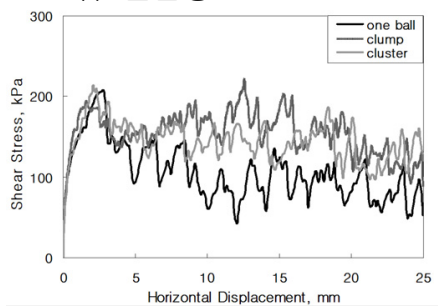

(ii) 결합강도 $1 \mathrm{MPa}$

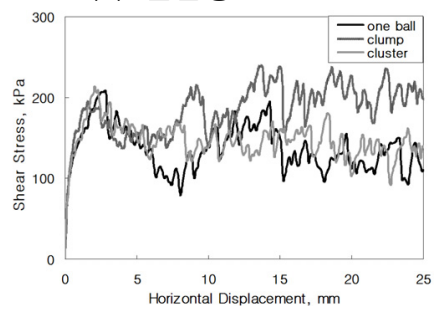

(iii) 결합강도 $3 \mathrm{MPa}$

(b) 거친 평면

그림 7. 입자 형상에 따른 접촉면의 응력-변위 곡선 


\section{5. 연속체 평면 모델링 방법에 따른 전단 거동}

연속체 평면에 존재하는 표면 돌출부의 파쇄 영향을 분석하기 위하여 입자요소 연속체 모델(ball 모델)과 같은 형상으로 하부박스의 입자 대신 wall로 연속체 표면을 모사한 경계요소 연속체 모델(wall 모델) 역시 모델링하였다. 이 때 경계요소 연속체 모델은 입자요소 연속체 모델과 달리, 돌출부의 파쇄가 불가능한 강성체이며, 이와 비교할 입자요소 연속체 모델은 돌출부의 파쇄가 전혀 발생하지 않는 경우로 한정하여 결합강도 $4 \mathrm{MPa}$ 을 적용하였다.

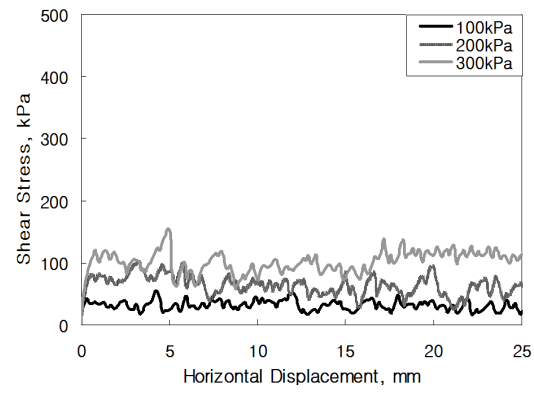

(i) 매끄러운 평면

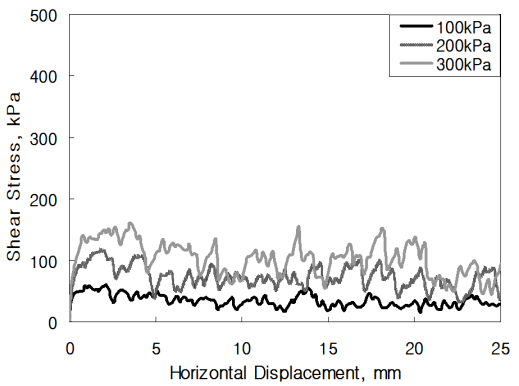

(ii) 중간 거칠기 평면

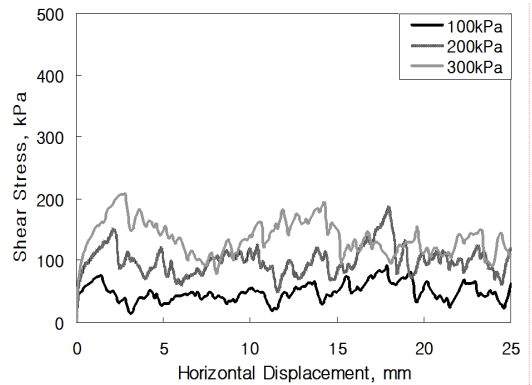

(iii) 거친 평면

(a) 입자요소 연속체 평면

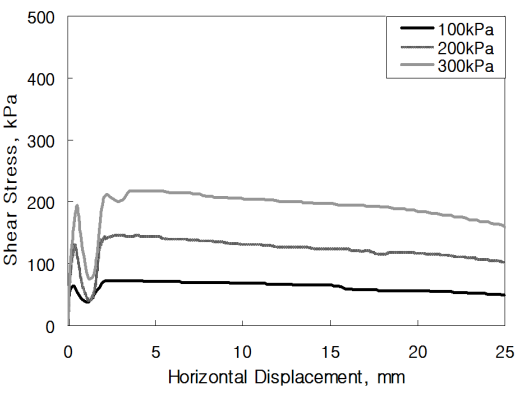

(i) 매끄러운 평면

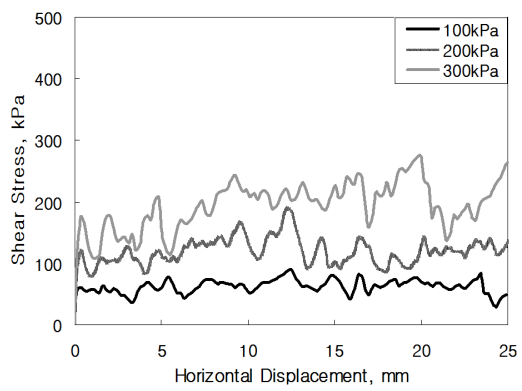

(ii) 중간 거칠기 평면

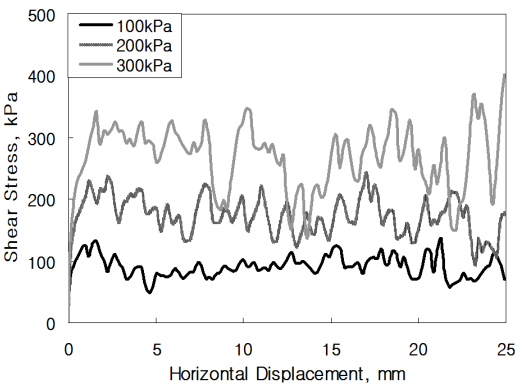

(iii) 거친 평면

(b) 경계요소 연속체 평면

그림 8. 연속체 모델링 방법에 따른 one ball 모델의 응력-변위 곡선 
그림 8은 수직하중에 따른 one ball 모델의 연속체 표면 거칠기별 응력-변위 곡선을 나타낸 것으로, 연속체 평면 모델링 방법에 따른 접촉면 전단강도를 비교하였다. 그 결과, 세 가지 표면 거칠기에 대하여 모두 입자요소 연속체 모델보다 경계요소 연속체 모델의 접촉면 전단강도가 더 크게 나타났다. 이는 입자요소 연속체는 돌출부 영역 또한 초기에 적용한 간극률에 따라 입자 사이에 간극이 존재하여 결합력을 주더라도 간극만큼의 압축이 가능하기 때문으로, 결과적으로 경계요소 연속체보다 경도(hardness)가 작은 효과라고 할 수 있다. 또한 입자요소 연속체와 경계요소 연속체에서 모두 돌출부 각도가 커질수록 접촉면 전단강도가 크게 나타났으나, 그 차이는 경계요소 연속체에서 더욱 뚜렷하게 확인할 수 있었다. 이는 강성체인 경계요소 연속체 모델은 돌출부가 본래 형상을 그대로 유지하는 반면, 입자요소 연속체 모델은 입자의 결합으로 이루어진 돌출부 형상이 전단이 진행됨에 따라 하중에 의해 입자간 간격이 좁아지는 등의 이유로 돌출부 형상이 달라지기 때문이다.

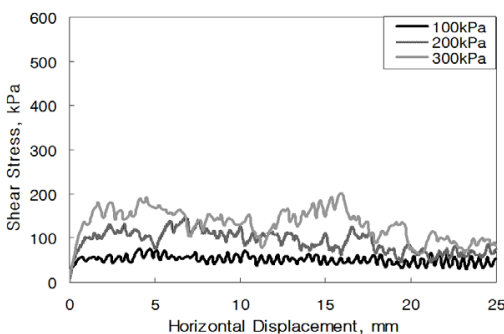

(i) 매끄러운 평면

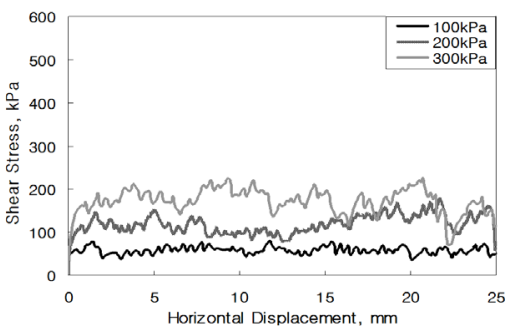

(ii) 중간 거칠기 평면

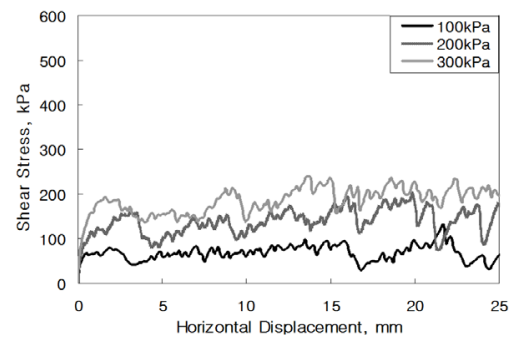

(iii) 거친 평면

(a) 입자요소 연속체 평면

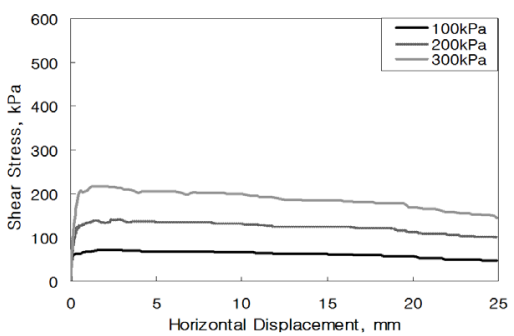

(i) 매끄러운 평면

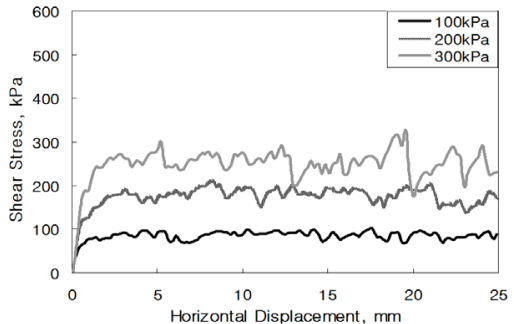

(ii) 중간 거칠기 평면

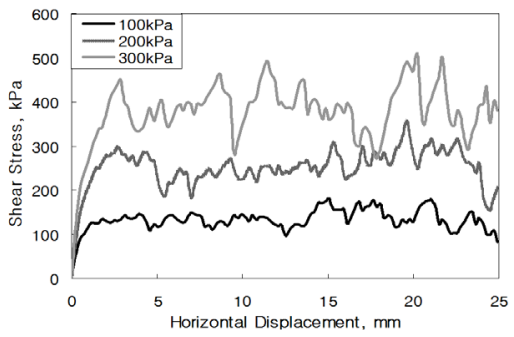

(iii) 거친 평면

(b) 경계요소 연속체 평면

그림 9. 연속체 모델링 방법에 따른 clump 모델의 응력-변위 곡선 
그림 9와 그림 10은 각각 clump 및 cluster 모델의 응력-변위 곡선을 연속체 모델링 방법에 따라 비교한 것으로, one ball 모델의 결과와 같이, 경계요소 연속체 모델의 접촉면 전단강도가 입자요소 연속체 모델보다 크게 나타났다.

한편 $100,200,300 \mathrm{kPa}$ 의 수직하중 조건에서 나타난 최대 접촉면 전단강도를 이용하여 그림 11 과 같은 파괴포락선을 그릴 수 있다. 파괴포락선은 입자의 파쇄가 발생하는 경우 비선형으로 나타나는데, 입자요소 연속체의 파괴포락선은 돌출부의 파쇄가 발생하지 않는 경우라도 전단에 의한 돌출부의 압축으로 인해 비선형을 나타내고, 경계요소 연속체의 경우는 입자 파쇄가 발생하는 cluster 모델의 파괴포락선만이 비선형을 띠고 있다. 반면, 매끄러운 평면에서는 미끄러짐 현상이 주된 전단 메커니즘으로 cluster 모델 또한 파쇄가 거의 발생하지 않아 선형적으로 거동한다. 접촉면 마찰각은 파괴포락선의 기울기 값으로, 표 2에 입자요소 연속체 및 경계요소 연속체 모델의 접촉면

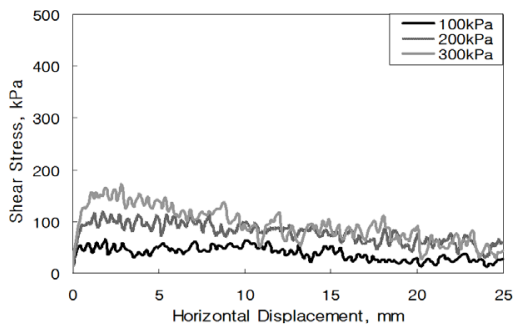

(i) 매끄러운 평면

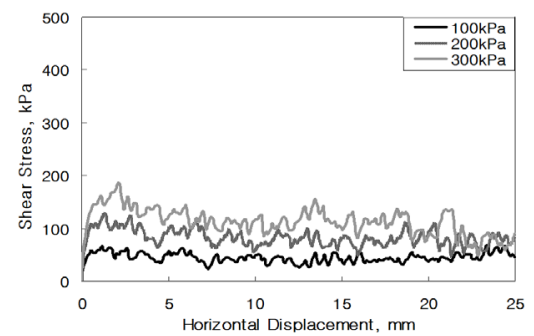

(ii) 중간 거칠기 평면

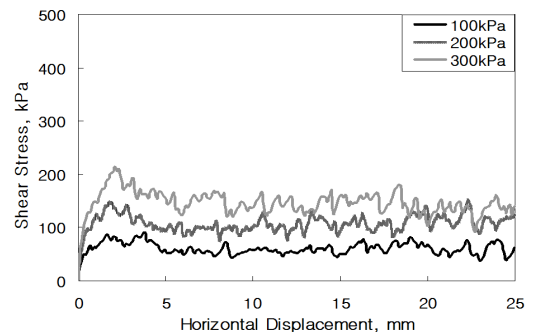

(iii) 거친 평면

(a) 입자요소 연속체 평면

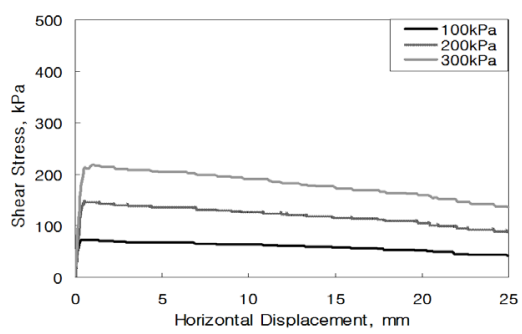

(i) 매끄러운 평면

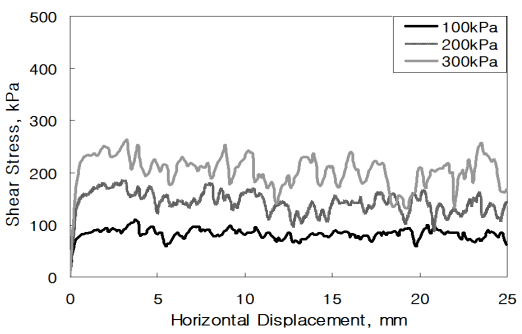

(ii) 중간 거칠기 평면

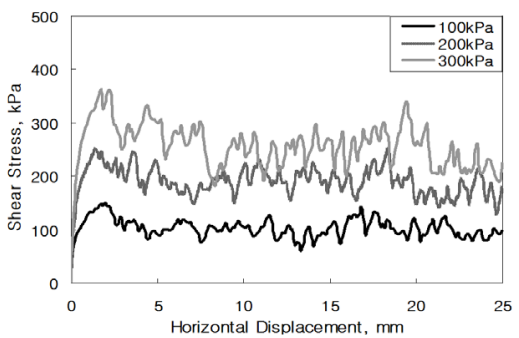

(iii) 거친 평면

(b) 경계요소 연속체 평면

그림 10. 연속체 모델링 방법에 따른 cluster 모델의 응력-변위 곡선 


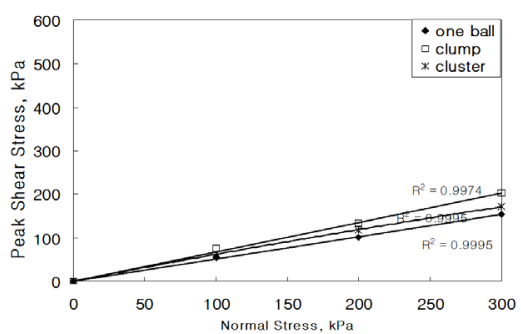

(i) 매끄러운 평면

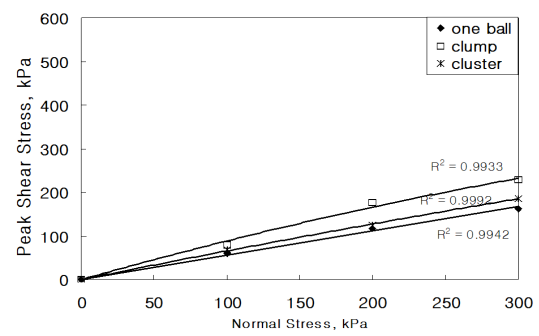

(ii) 중간 거칠기 평면

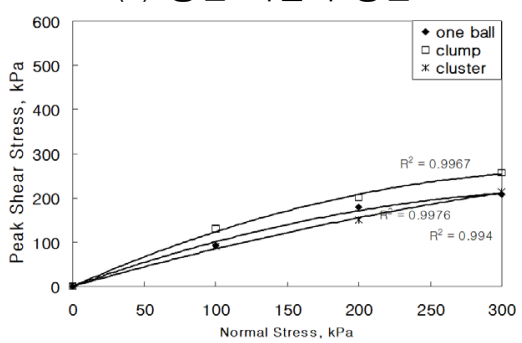

(iii) 거친 평면

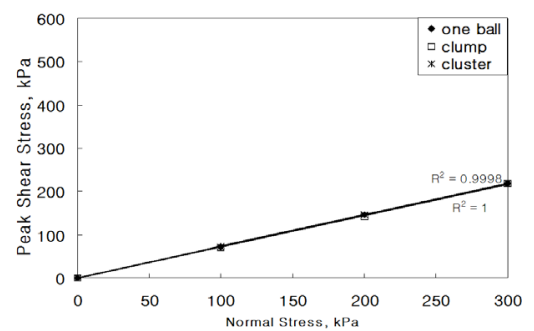

(i) 매끄러운 평면

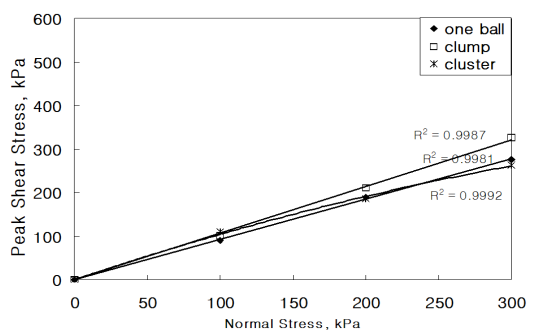

(ii) 중간 거칠기 평면

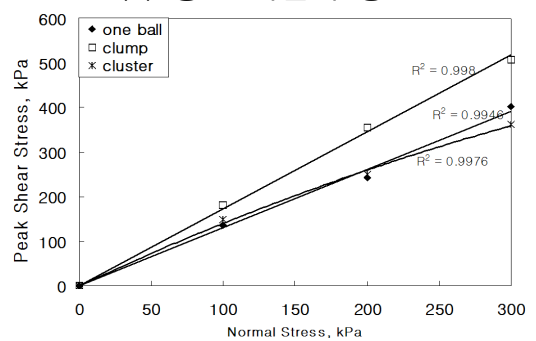

(iii) 거친 평면

(a) 입자요소 연속체 평면

(b) 경계요소 연속체 평면

그림 11. 입자요소 vs. 경계요소 연속체의 파괴포락선 비교

표 2. 입자요소 vs. 경계요소 연속체 접촉면 마찰각( $\left(^{\circ}\right)$ 비교

\begin{tabular}{|c|c|c|c|c|}
\hline & & 매끄러운 평면 & 중간 거칠기 평면 & 거친 평면 \\
\hline \multirow{3}{*}{$\begin{array}{l}\text { 입자요소 } \\
\text { 연속체 }\end{array}$} & One ball & 27.18 & 29.08 & 37.55 \\
\hline & Clump & 34.09 & 39.41 & 42.96 \\
\hline & Cluster & 30.14 & 32.06 & 36.38 \\
\hline \multirow{3}{*}{$\begin{array}{c}\text { 경계요소 } \\
\text { 연속체 }\end{array}$} & One ball & 36.02 & 42.74 & 52.54 \\
\hline & Clump & 35.83 & 46.99 & 59.93 \\
\hline & Cluster & 36.08 & 42.2 & 51.13 \\
\hline
\end{tabular}

마찰각을 비교하여 나타내었다. 그 결과, 접촉면 전단강도가 큰 경계요소 연속체가 상대적으로 큰 접촉면 마찰각을 나타났고, 모든 입자모델에서 연속체의 표면 거칠기가 거칠수록 큰 접촉면 마찰각을 가졌으며, 입자 형상에 대해서는 clump 모델이 가장 큰 값을 나타냈다. 


\section{6. 결 론}

본 연구에서는 연속체 평면의 표면 거칠기에 따른 입자와 연속체 평면의 접촉면 전단 거동 특성을 분석하기 위하여 개별요소법 프로그램인 $\mathrm{PFC}^{2 \mathrm{D}}$ 를 사용하였다. 접촉면 전단으로 인한 입자 및 연속체 평면의 파쇄 발생을 관찰하여 입자 및 평면의 파쇄가 접촉면 전단거동에 미치는 영향을 분석하였다. 본 연구에서 얻은 주요 결과를 요약하면 다음과 같다.

1. 연속체 평면에 존재하는 표면 돌출부의 파쇄를 모사하기 위하여 $\mathrm{PFC}^{2 \mathrm{D}}$ 에서 지원하는 입자요소 (ball)로 연속체 평면을 모델링하였다. 이 때 연속체 평면의 결합강도에 변화를 주어 그에 따른 입자 및 연속체 돌출부의 파쇄 유형을 분석한 결과, 매끄러운 평면에서는 전단 초기 최대 접촉면 전단강도가 뚜렷이 나타나지 않았으나, 중간 거칠기 평면 및 거친 평면에서는 뚜렷이 나타났다. 또한 결합강도가 작을수록 파쇄가 빨리 발생하여 큰 결합강도를 가진 연속체 모델보다 작은 접촉면 전단강도를 보였다. 돌출부의 파쇄가 발생한 후, 접촉면 전단강도는 수렴하는 경향을 보이며, 평면 결합강도 $700 \mathrm{kPa}$ 모델의 파쇄 영역이 가장 크게 나타났고, 결합강도가 클수록 돌출부의 파쇄가 적게 발생하였다. 또한 중간 거칠기 평면보다 거친 평면의 접촉면 전단강도가 크게 나타났으며, 거친 평면에서 최대 접촉면 전단강도를 더 뚜렷하게 발견할 수 있다.

2. 연속체 평면에 존재하는 표면 돌출부의 파쇄 영향을 분석하기 위하여 입자요소 연속체 모델과 같은 형상의 경계요소 연속체를 모델링하였다. 경계요소 연속체 모델은 돌출부의 파쇄가 불가능한 강성체이므로, 상부박스의 모든 입자 모델에 대하여 입자요소 연속체의 접촉면 전단강도보다 크게 나타났다. 이는 입자요소 연속체는 돌출부 영역에도 입자 사이에 간극이 존재하여 결합력을 주더라도 간극만큼의 압축이 발생하므로, 경계요소 연속체보다 경도(hardness)가 작은 효과라고 할 수 있다.

3. 수직하중 조건이 각각 $100 \mathrm{kPa}, 200 \mathrm{kPa}, 300 \mathrm{kPa}$ 일 때의 최대 접촉면 전단강도로부터 각 모델에 대한 접촉면 마찰각을 구한 결과, 접촉면 전단강도가 큰 경계요소 연속체가 입자요소 연속체보다 큰 값을 나타냈고, 모든 입자 모델에서 연속체의 표면 거칠기가 거칠수록 큰 접촉면 마찰각이 나타났다.

\section{감사의 글}

“이 논문은 2010년도 정부(교육과학기술부)의 재원으로 한국연구재단의 지원을 받아 수행된 기초연구사업임.(No. 2010-0022941)" 이에 감사드립니다. 


\section{참 고 문 헌}

1. 김도훈, 이강현, 이인모 (2011), “침투를 고려한 원형수직터널 거동특성 연구”, 한국터널지하공간학회논문집, 제13권, 제6호, pp. 431-450.

2. 이성원, 정재형, 김창용, 배규진, 이주공, 박경호 (2009), “원형터널에서 지반-라이닝 상호작용에 대한 수학적 해석해에 관한 연구”, 한국터널지하공간학회논문집, 제11권, 제4호, pp. 427-435.

3. 조인성, 박정준, 김종선, 이인모 (2010), “천공홀 가압 팽창 개념을 도입한 터널 보조 신공법 연구”, 한국터널 지하공간학회논문집, 제12권, 제6호, pp. 407-416.

4. Brumund, W.F., Leonards, G.A. (1973), "Experimental study of static and dynamic friction between sand and typical construction materials", ASTM Journal of Testing and Evaluation, Vol. 1, No. 2, pp. 162-165.

5. Cundall, P.A., Strack, O.D.L. (1979), "A discrete numerical model for granular assemblies", Geotechnique, Vol. 29, No. 1, pp. 47-65.

6. Dove, J.E., Frost, J.D., Han, J., Bachus, R.C. (1997), "The influence of geomembrane surface roughness on interface strength”, Proc. Geosynthetics '97, Vol. 2, pp. 863-876.

7. Feda, J. (2002), "Notes on the effect of grain crushing on the granular soil behavior", Engineering Geology, Vol. 63, pp. 93-98.

8. Frost, J.D., Lee, S.W., Cargill, P.E. (1999), "The evolution of sand structure adjacent to geomembranes", Proc. Geosynthetics '99, Vol. 1, pp. 559-573.

9. Hainbuchner, E., Potthoff, S., Konietzky, H., te Kamp, L. (2002), "Particle based modeling of shear box tests and stability problems for shallow foundations in sand", Numerical Modeling in Micromechanics via Particle Methods, Vol. 1, pp. 151-156.

10. Itasca Consulting Group, Inc. (2004), Particle flow code in 2-dimensions, Ver.3.1 User's manual.

11. Jensen, R.P. (1998), "Numerical and analytical modeling of the microstructural behavior of a particulate media-structure interface", Ph. D. Thesis, School of Civil Engineering, University of Wisconsin-Madison, 121p.

12. Jo, S.A., Kim, E.K., Cho, G.C., Lee S.W. (2011), "Particle shape and bonding state effects on particle crushing in PFC", Soils and Foundations, Vol. 51, No. 4, pp. 701-712.

13. Lee, S.W. (1998), "Influence of surface topography on interface strength and counterface soil structure", Ph.D. Thesis, School of Civil and Environmental Engineering, Georgia Institute of Technologh, Atlanta, Georgia, USA, 336p.

14. Lobo-Gurrero, S., Vallejo, L.E. (2005), "Crushing a weak granular material: experimental numerical analyses”, Geotechnique, Vol. 55, No. 3, pp. 245-249. 
15. Paikowsky, S.G., Player, C.M., Connors, P.J. (1995), “A dual interface apparatus for testing unrestricted friction of soil along solid surfaces”, ASTM Geotechnical Tesing Journal, Vol. 18, No. 2, pp. 168-193.

16. Potyondy, J.G. (1961), "Skin friction between various soils and construction materials", Geotechnique, Vol. 11, pp. 339-355.

17. Uesugi, M., Kishida, H., Tsubakihara, Y. (1988), "Behavior of sand particles in sand-steel friction", Soils and Foundations, Vol. 28, No. 1, pp. 107-118. 